\title{
REQUIREMENTS CONTRACTS UNDER THE UNIFORM COMMERCIAL CODE
}

The merchant whose selling market is subject to fluctuation often seeks a means, perhaps at a constant price, to assure a source of supply for his raw materials which will relieve him of the burden of predicting his needs beyond the time required for production. The common method of accomplishing this is to negotiate a requirements contract whereby the buyer binds himself to purchase all of his requirements from the seller in exchange for a promise from the seller to supply the buyer's needs. A manufacturer, wishing to avoid the problem of correlating his production with future demand, may seek an output contract in which he binds himself to, sell all of his production to the buyer in return for the latter's promise to take all of the output. In this way the seller may shift the burden of marketing his production. Since the problems of output and requirements contracts are in many respects similar, this Note will utilize the term requirements contract to refer generally to both types of agreements. ${ }^{1}$

Requirements contracts have been held void by courts which took the view that the terms of the agreement were too uncertain to be enforced, or that since the buyer did not bind himself to have requirements, performance of the contract depended on the buyer's whim and therefore lacked consideration. $^{2}$ More recent authority, however, recognizes that in the bargained-for exchange of promises each party has limited his freedom to some extent and that the terms "requirements" or "needs" supply a sufficiently objective standard to be enforceable. ${ }^{3}$ Thus, today, the typical re-

1. On output contracts generally, see 1 WILIISTON, ConTracts $\$ 104$ (a) (Williston and Thompson's ed. 1936); 2 WILLISTON, SaLES \$464 (1924); Havighurst and Berman, Requirement and Output Contracts, 27 ILL L. Rev. 1' (1932); Notes, 2 Duke B.J. 180 (1952) ; 29 CoL. L. REv. 223 (1928).

2. See, e.g., Bailey v. Austrian, 19 Minn. 535 (1873); Schlegel Mfg. Co. v. Cooper's Glue Factory, 231 N.Y. 459, 132 N.E. 148 (1921) (contract for requirements of "Special BB" glue held invalid since buyer did not bind self to have requirements or not to sell other glue in competition). The view has been expressed that the Schlegel decision was in part motivated by a desire to permit seller to avoid a bad deal. See Havighurst and Berman, supra note 1 , at 5 .

3. See, e.g., El Rio Oil Itd. v. Pacific Coast Asphalt Co., 95 Cal. App. 186, 213 P.2d 2 (1949); Matter of McNutt Co. v. Eckert, 257 N.Y. 100 , 177 N.E. 386 (1931), citing Edison Elec. Illuminating Co. v. Thacher, 229 N.Y. 172, 128 N.E. 124 (1920); Texas Co. v. Pensacola Maritime Corp., 279 Fed. 19 (5th Cir. 1922). In drafting a requirements contract, the language used should be fairly precise in order to avoid a finding that there had been no binding agreement made by one party. The obligation of one party to supply and the other to take requirements must be definite. See Hoffmann v. Pfingsten, 260 Wis. 160, 50 N.W.2d 369 (1951); Stradling v. Allied Housing Associates, Inc., 349 Pa. 405, 37 A.2d 585 (1944); Wickham \& Burton Coal Co. v. Farmers' Lumber Co., 189 Iowa 1183, 179 N.W. 417 (1920). However, the preciseness of language required by some courts may be lessened by the Uniform Commercial Code requirement that the agreement be construed in light of reasonable commercial intent. See UCC $\$ 2-306$, comment 1 (Official Draft 1952).

All references to the Uniform Commercial Code (referred to throughout this Note as UCC) are to the Official Draft of the Uniform Commercial Code as proposed by the American Law Institute and the National Conference of Commissioners on Uniform Laws, Text and Comments Edition (1952). The only state to adopt the 
quirements contract is generally held valid. ${ }^{4}$ Once enforceability is established the problem arises as to the extent of the obligation undertaken by each of the parties to the contract. Numerous problems such as the buyer's obligation to remain in business, or the capacity at which a buyer's operations should continue, leave the law in this area somewhat uncertain. The Uniform Commercial Code ${ }^{5}$ specifically recognizes the validity of requirements contracts and undertakes to define the extent of obligations by implying an agreement between the parties to act in good faith. ${ }^{6}$ This Note will attempt to compare requirements contract law as it has existed without the Code with the proposed law under the Code, ${ }^{7}$ and point to some of the problems which may remain unsolved by the Code.

\section{VALIDITy OF the Contract}

While courts generally find that the buyer who seeks to make a requirements contract has, in promising not to buy his requirements elsewhere, given a commitment sufficient and certain enough to support a binding contract, ${ }^{8}$ there are some circumstances in which there is doubt as to whether the buyer has obligated himself at all, or for an amount certain enough to be enforceable. These problems of sufficiency of buyer's obligation and of certainty occur where the buyer is a non-manufacturing establishment, such as a jobber, and also where the buyer has no estab-

Code to date is Pennsylvania where it will take effect on July 1, 1954. See PA. Srat. ANn. tit. 12A (Purdon Supp. 1953). In enacting the UCC into law, Pennsylvania retained the same section numbers found in the official draft. Therefore, no citation will be given to the Pennsylvania statute.

4. See 1 Wirliston, Contracrs $\$ 104 \mathrm{~A}$ (Williston and Thompson's ed. 1936).

5. For discussions of the Sales Article generally, see Hall, From Status to Contract? [1952] WIs. L. REv. 3; Corbin, The Uniforn Conmercial Code-Sales; Should It Be Enacted?, 59 YALE L.J. 821 (1950); Rabel, The Sales Law in the Proposed Uniform Commercial Code, $17 \mathrm{U}$. of CHI. L. REv. 427 (1950); Williston, The Law of Sales in the Proposed Uniform Commercial Code, 63 HARv. L. Rev. 561 (1950).

6. There is, however, an exception to the good faith rule that prohibits tender or demand of any amount unreasonably disproportionate to any estimate, or in the absence of an estimate to past requirements. See text at note 17 infra.

7. The UCC $\$ 2-306(1)$ provides:

"(1) A term which measures the quantity by the output of the seller or the requirements of the buyer means such actual output or requirements as may occur in good faith, except that no quantity unreasonably disproportionate to any stated estimate or in the absence of a stated estimate to any normal or otherwise comparable prior output or requirements may be tendered or demanded."

A related problem embodying considerations similar to requirements contracts is that of the exclusive dealing contract dealt with in UCC $\$ 2-305(2)$ : "Where in connection with a contract for sale there is a lawful agreement for exclusive dealing by either the seller or the buyer in the kind of goods concerned, good faith also imposes on each party an obligation of due diligence."

Apparently $\$ 2-306(2)$ is based on the famous case of Wood v. Lucy, Lady Duff-Gordon, 222 N.Y. 88, 18 N.E. 214 (1917) in which the court said that an exclusive dealing contract impliedly imposes upon the dealer the duty to devote reasonable efforts to sell the goods.

8. See, e.g., Texas Co. v. Pensacola Maritime Corp., 279 Fed. 19 (5th Cir. 1922) ; Jenkins \& Co. v. Anaheim Sugar Co., 247 Fed. 958 (9th Cir. 1918), cert. denied, 257 U.S. 658 (1922); Trainor v. Buchanan Coal Co., 154 Minn. 204, 191 N.W. 431 (1923). 
lished business at the time of making the contract, but signs a requirements contract in contemplation of entering business.

Most courts will enforce a jobber's contract, ${ }^{9}$ but a minority has refused to do so, reasoning that since there is no physical plant by which needs may be measured or reasonably approximated, the contract is simply for what buyer chooses to buy or for an amount incapable of approximation and is therefore uncertain or lacks consideration..$^{10}$ In a falling market, these courts have observed, a jobber could avoid loss if there were no requirements, and requirements might be avoided simply by securing no customers.

The comments to the requirements section of the Uniform Commercial Code state that a contract for the requirements of a non-manufacturing establishment is included.11 Validation of a jobber's contract, like validation of requirements contracts generally, would seem to be a logical result of the Code's implication of a good faith standard. If the jobber has an obligation to have good faith requirements, he has a duty which is both binding and capable of measurement for purposes of enforcement; the problem is no longer one of validity of the contract, but of defining the good faith duty of the parties. The Code's attempt to facilitate a definition of good faith in any situation will be discussed below. ${ }^{12}$

A contract for the requirements of a non-established business is, like a jobber's contract, subject to the possible charge of invalidity for uncertainty or lack of consideration, for here, too, there is no existing physical plant by which to measure requirements. Some courts have found contracts for the requirements of a non-established business void for this reason; ${ }^{13}$ one court found sufficient consideration in the buyer's implied promise not to buy from another; ${ }^{14}$ another held the contract subject to an implied condition that the buyer actually have begun business by the time deliveries are to begin. ${ }^{25}$ Neither the Code nor comments specifically deals

9. See, e.g., Baker v. Murray Tool \& Supply Co., 137 Okla. 288, 279 Pac. 340 (1929) ; Pittsburgh Plate Glass Co. v. Neuer Glass Co., 253 Fed. 161 (6th Cir. 1918); Minnesota Lumber Co. v. Whitebreast Coal Co., 160 Ill. 85, 43 N.E. 774 (1895). See also 1 Corbin, Contracts $\$ 156$ (1950).

10. Nassau Supply Co. v. Ice Service Co., 252 N.Y. 277, 169 N.E. 383 (1929); cf. Hoffmann v. Pfingsten, 260 Wis. 160,50 N.W.2d 369 (1951).

11. UCC §2-306, comment 1 .

12. See text at note 17 infra.

13. American Trading Co. v. National Fiber and Insulation Co., 31 Del. 65, 111 Atl. 290 (1920); Pessin v. Fox Head Waukesha Corp., 230 Wis. 277, 282 N.W. $582(1939)$.

14. "The contract was an undertaking on the purchaser's part to buy all of its requirements at Pensacola from the defendant. . . The defendant agreed to sell to plaintiff all such requirements up to certain fixed quantities. Here was the consideration of a promise both to do and to refrain from doing a certain thing as a consideration for the promise to sell certain goods at fixed prices. . . " Texas Co. v. Pensacola Maritime Corp., 279 Fed. 19, 23 (5th Cir. 1922).

15. Nassau Supply Co. v. Ice Service Co., 252 N.Y. 277, 169 N.E. 383 (1929). Since the contract is for requirements, not demands, a buyer will not be allowed to stock up in anticipation of future needs before he begins business and actually has requirements. See Dowd v. Hercules Powder Co., 66 Colo. 302, 181 Pac. 767 (1919). Such a limitation is continued by the stipulation of the UCC that the contract is for "actual" needs. 
with non-established businesses, although the similarity of this problem to that of the jobber suggests that these contracts are also valid under the Code. Where a buyer expecting to enter business makes a requirements contract, the Code's implication that he has agreed to take his good faith requirements would logically mean that he has a duty to undertake the new enterprise, with its resulting requirements, except for a good faith reason; this duty should provide adequate consideration for the contract. The problem of certainty of the contract may be more perplexing here than where a jobber's contract is involved. The jobber at least has an existing business set-up, the normal operation of which can provide some stability to his requirements; but the extent of the non-established buyer's good faith obligation may be difficult to prove in a subsequent suit for enforcement. Where the contemplated scope of the enterprise can be determined, the good faith standard makes possible a definition of the buyer's obligation, and should therefore save the contract from lack of certainty; but where the parties' intentions in respect to size of the new enterprise are unrevealed, courts which presently hold such contracts void may find no change made by the Code.

\section{Extent of THE ObLigation}

Most current problems in the area of requirements contracts occur not in establishing the validity of the contract, but in defining the extent of the obligations created by an admittedly enforceable contract. While the amount of goods to be supplied under the contract is inherently flexible, there are some limits to the minimum demands which will fulfill the buyer's obligation and the maximum which the seller can be expected to supply. Under current law, these limits are in some respects diverse or uncertain; courts generally indicate that they apply a good faith standard to determine obligations, but there is no clear agreement as to the meaning of good faith. 18

The Code implies an agreement that requirements are to be those occurring in good faith, except that the buyer's demands may not exceed an amount reasonably proportionate to any stated estimate or "to any normal or otherwise comparable prior" demand. ${ }^{17}$ As to the meaning of good faith, the general definitions section of the Code defines it as "honesty in fact in the conduct or transaction concerned." 18 But, as the comment to that section ${ }^{19}$ points out, in other sections of the Code more

16. See, e.g., Kellogg Co. v. Standard Steel Fabricating Co., 189 F.2d 629 (10th Cir. 1951) (where estimate of 125 tons, buyer not bound to take more than 51 tons absent a showing of "bad faith") ; Poston v. Western Dairy Products Co., 129 Wash. 73, 36 P.2d 65 (1934) (breach of contract where buyer's requirements diminished as a result of buyer's disparagement of seller's product to consumers in favor of competing product); Dailey Co. v. Clark Can Co., 128 Mich. 591, 87 N.W. 761 (1901) (increase in requirements due to buyer's price cutting to create demand held good faith).

17. See text at note 62 infra for discussion of effect of previous requirements.

18. UCC $\$ 1-201(19)$.

19. UCC §1-201, comment 19. 
than "honesty in fact" is required; for instance, in the Sales Article, which contains the requirements contract section, good faith includes "observance of reasonable commercial standards" insofar as merchants' transactions are concerned..$^{20}$ That the framers of the Code intended to impose upon merchants a higher standard of conduct than "honesty in fact" is specifically stated in the comments to a section of the Commercial Paper Article which also defines good faith in terms of "reasonable commercial standards" : 21

“. . The 'reasonable commercial standards' language added here and incomparable [sic] provisions elsewhere in the Act, e.g., Section 2-103, merely makes explicit what has long been implicit in caselaw handling of the 'good faith' concept. A business man engaging in a commercial transaction is not entitled to claim the peculiar advantages which the law accords to the good faith purchaser .. . on a bare showing of 'honesty in fact' when his actions fail to meet the generally accepted standards current in his business, trade or profession." 22

Whether or not such a standard has been "long implicit in case-law" 23 in the requirements contract area, it is clear that reasonable commercial standards is a vital measuring stick of requirements contracts under the Code. The actual content of this standard can only be refined in connection with each of the specific problems which arises in attempting to determine the extent of the parties' obligations.

\section{Duty to Enter Business}

Where a buyer contracts to take the requirements of a business which he has not yet established, assuming the validity of the contract, there remains the problem of whether, or under what circumstances, failure or delay in embarking on the business venture constitutes a breach by the buyer. The problem is illustrated by Texas Co. v. Pensacola Maritime Corp. ${ }^{24}$ where buyer, after having taken no requirements for the first seven months of a contract for his requirements of bunker oil, began to sell to ships and demanded oil from seller under the contract. When seller refused to supply him, buyer sued for breach. The court held immaterial the absence of purchases during the first seven months, despite the fact that buyer's lack of requirements may have been dictated by considerations of price, since requirements began when prices of oil rose.

20. UCC §2-103(1) (b).

21. UCC $\$ 3-302(1)(b)$.

22. UCC \$3-302, comment 1.

23. Compare Southwest Natural Gas Co. v. Oklahoma Portland Cement Co., 102 F.2d 630 (10th Cir. 1939) ; New York Central Ironworks Co. v. United States Radiator Co., 174 N.Y. 331, 66 N.E. 967 (1903), with Brawley v. United States, 96 U.S. 168 (1877) ; Keener Oil \& Gas Co. v. Consolidated Gas Util. Corp., 190 F.2d 985 (10th Cir. 1951).

24. 279 Fed. 19 (5th Cir. 1922). 
Under the Code courts may, to assure consideration by the buyer, hold that the duty to have good faith requirements includes a duty not to delay the entry into business in order to avoid loss under the contract. According to this view, where failure to embark on the enterprise is due to lack of capital, ${ }^{25}$ technological changes, ${ }^{26}$ ill health, or some equally compelling reason, it would probably meet the Code's good faith requirement, but in a situation like Texas $\mathrm{Co}$. the Code would require close scrutiny of buyer's motives for the delay in having requirements. An especially difficult problem would be presented if buyer claims to have abandoned the projected venture not for some compelling reason such as lack of capital or technological changes, but as a matter of personal choice unrelated to any considerations of the requirements contract. An analogy to existing law which defines buyer's duty to stay in business in a similar situation suggests that here the buyer might be held to his contract. ${ }^{27}$

On the other hand, courts faced with the question of buyer's duty to enter business may be reluctant to impose such a duty, and may avoid this imposition by holding the contract to be subject to the condition precedent that buyer enter business. ${ }^{28}$ In this case, consideration for the contract would be provided by buyer's agreement to buy only from seller if he does enter business; ${ }^{29}$ buyer could refrain from entering business for any reason at all..$^{30}$

\section{Duty to Remain in Business}

A requirements contract may not deal expressly with the problem raised when one party to it abandons or sells his business before the period stated by the contract has elapsed. ${ }^{81}$ The cases seem to indicate that there is an obligation to remain in business unless to do so would be economically unjustified, as where the requirements buyer's market has virtually disappeared and he closes his plant, 32 a confiscatory tariff makes it impossible for the output seller to continue production, ${ }^{33}$ or some other impossibility

25. Cf. Kenan, McKay \& Spier v. Yorkville Cotton Oil Co., 260 Fed. 28 (4th Cir. 1919) (discontinued business).

26. Southwest Natural Gas Co. v. Oklahoma Portland Cement Co., 102 F.2d 630 (10th Cir. 1939); McKeever Cook \& Co. v. Canonsburg Iron Co., 138 Pa. 184, 20 Atl. 938 (1890).

27. See notes 35 and 39 infra.

28. No particular form of words is necessary to create a condition precedent, such a finding being a matter of interpretation. Restatensent, CoNTRACTS § 258 (1932).

29. See 1 Corbin, Contracts $\$ \$ 156,157$ (1950); 1 Wirziston, Contracts $\S 104 \mathrm{~A}$ (Williston and Thompson's ed. 1936).

30. The fact that the condition is some performance by one of the parties and that that party refuses to perform the act on which contractual obligations are dependent does not alone constitute a breach. Restatensent, Contracts \$ 257 (1932).

31. See, for example, the contract involved in Atwater \& Co. v. Terminal Coal Corp., 115 F.2d 887 (1st Cir. 1940).

32. Fort Wayne Corrugated Paper Co. v. Anchor Hocking Glass Corp., 130 F.2d 471 (3d Cir, 1942).

33. Sheesley v. Bisbee Linseed Co., 337 Pa. 197, 10 A.2d 401 (1940). 
intervenes, such as destruction of buyer's business. ${ }^{34}$ On the other hand, buyer's mere desire to be rid of the business or to avoid some risk of loss does not justify cessation. ${ }^{35}$ Substantial reliance by the other party is sometimes an important factor in reaching the conclusion that cessation is unjustified. ${ }^{36}$ It should be noted, however, that the language used in some of these cases is somewhat broader than the holdings on the facts. Some opinions indicate that there is no obligation to remain in business at all, while others would apparently permit no excuse other than impossibility. ${ }^{38}$ Nevertheless, the great majority imply a good faith standard by which reasons for cessation are to be measured. ${ }^{39}$

The Code treatment of this problem seems to be in accord with the prevailing rules, ${ }^{40}$ since reasonable commercial standards should relieve buyer of a duty to continue in business where continuance would result in a serious loss for reasons other than the requirements contract, but should prohibit cessation merely to avoid the contract or to avoid a minor loss. The Code's adoption of the prevailing rules would remove any uncertainty which may exist in those states which have indicated that they either imply no obligation to remain in business ${ }^{41}$ or excuse cessation only for impossibility. ${ }^{42}$

\section{Definition of Requirements}

Without the Code:-Where the courts are called upon to determine whether buyer is ordering too much or too little under a requirements contract, they look to several factors to determine the parties' intentions. Where a maximum or minimum amount is specified by the contract, courts of course give effect to that provision. ${ }^{43}$ An estimate of expected require-

34. The rule of excuse from performance due to supervening impossibility is, of course, not peculiar to requirements contracts but is one of general application. See Restatement, Contracts $\$$ 454-467 (1932).

35. Diamond Alkali Co. v. Tomson \& Co., 35 F.2d 117 (3d Cir. 1929) ; Great Lakes \& St. Lawrence Trans. Co. v. Scranton Coal Co., 239 Fed. 603 (7th Cir. 1917); Wigand v. Bachman-Bechtel Brewing Co., 222 N.Y. 272, 118 N.E. 518 (1918). But cf. Drake v. Vorse, 52 Iowa 417, 3 N.W. 465 (1879).

36. Diamond Alkali Co. v. Tomson \& Co., supra note 35.

37. Drake v. Vorse, supra note 35; Helena Light \& Ry. v. Northern Pac. Ry., 57 Mont. 93, 186 Pac. 702 (1920).

38. See, e.g., Cragin Products Co. v. Fitch, 6 F.2d 557 (8th Cir. 1925). Cf. Wells v. Alexandre, 130 N.Y. 642, 29 N.E. 142 (1891) (even though defendant sold ships and went out of business he was held liable on requirements contract for the amount of coal which the ships used during year).

39. Sheesley v. Bisbee Linseed Co., 337 Pa. 197, 10 A.2d 401 (1940) ; Fort Wayne Corrugated Paper Co. v. Anchor Hocking Glass Co., 130 F.2d 471 (3d Cir. 1942); Du Boff v. Matam Corp., 272 App. Div. 502, 71 N.Y.S.2d 134 (1st Dep't 1947); Great Lakes \& St. Lawrence Trans. Co. v. Scranton Coal Co., 239 Fed. 603 (7th Cir. 1917).

40. I.e., that good faith business reasons will excuse cessation. See, e.g., Sheesley v. Bisbee Linseed Co., 337 Pa. 197, 10 A.2d 401 (1940) ; Fort Wayne Corrugated Paper Co. v. Anchor Hocking Glass Co., 130 F.2d 471 (3d Cir. 1942); cf. Du Boff v. Matam Corp., 272 App. Div. 502, 71 N.Y.S.2d 134 (1st Dep't 1947).

41. See cases cited note 37 supra.

42. See cases cited note 38 supra.

43. Minnesota Lumber Co. v. Whitebreast Coal Co., 160 I1l. 85, 43 N.E. 774 (1896) ; Diamond Alkali Co. v. Aetna Explosives Co., 264 Pa. 304 (1919). 
ments contained in a contract may, without the Code, be treated as having been made simply for the convenience of the parties and of no operative significance.44 For example, a contract calling for defendant's output of cotton linters, "about 400 bales," was held not to have been breached when defendant supplied only 155 bales, absent a showing that the reduced production was motivated by bad faith. ${ }^{45}$ A similar result was obtained where the contract was for "approximately 125 tons" of steel, and only 51 tons were required. ${ }^{48}$

In the absence of any stated minimum or maximum, some courts have said that the requirements are measured only by buyer's actual needs so long as he buys only from seller. ${ }^{47}$ Most courts, however, use buyer's past requirements as a guide; some have even refused to enforce requirements contracts when there are no past requirements by which the conduct of the parties might be measured.88 The deviation typically permitted from past requirements is one in the normal course of business and not for purposes of exploitation or expansion; frequently courts talk in terms of a "good faith" deviation ${ }^{49}$ but no clear formulation of "good faith" has been made. For example, where at the time of execution of a requirements contract for bituminous coal a school board had been using 1000 tons of bituminous and an equivalent amount of anthracite, and the board removed the anthracite burners shortly thereafter, bituminous seller could not be forced to supply 2200 tons at the contract price.50 Although the court stated that the price of bituminous coal advanced around the time the anthracite burners were removed, there was no clear indication of bad faith -in buyer's attempt to secure 2200 tons under the contract; it is the fact that buyer used anthracite as well as bituminous at the time the contract was made which persuaded the court. However, the court added that if enlargement of the school buildings, increased attendance, or weather conditions had caused the increased demand, rather than the unforeseeable removal of the anthracite burners, seller would have had to supply this demand under the contract. ${ }^{51}$ Similarly, where a requirements seller at-

44. Brawley v. United States, 96 U.S. 168 (1877); Cragin Products Co. v. Fitch, 6 F.2d 557 (8th Cir. 1925); Holmes \& Co. v. Detroit, 158 Mich. 137, 122 N.W. 506 (1909); cf. Andrews Coal Co. v. Board of Directors, 151 La. 695, 92 So. 303 (1922). But cf. Poland Coal Co. v. Rogers, $260 \mathrm{~Pa} .118,103$ Atl. 559 (1918). 1919).

45. Kenan, McKay \& Spier v. Yorkville Cotton Oil Co., 260 Fed. 28 (4th Cir. 1951).

46. Kellogg Co. v. Standard Steel Fabricating Co., 189 F.2d 629 (10th Cir.

47. E.g., Dailey Co. v. Clark Can Co., 128 Mich. 591, 87 N.W. 761 (1901).

48. See cases cited note 13 supra.

49. E.g., Kenan, McKay \& Spier v. Home Fertilizer \& Cotton Oil Co., 202 Ala. 29, 79 So. 367 (1918); New York Central Ironworks Co. v. United States Radiator Co., 174 N.Y. 331, 66 N.E. 967 (1903) ; Kellogg Co. v. Standard Steel Fabricating Co., 189 F.2d 629 (10th Cir. 1951).

50. Andrews Coal Co. v. Board of Directors, 151 La. 695, 92 So. 303 (1922) (the contract also contained an estimate, but the court accorded little weight to this factor).

51. Id. at 701, 92 So. at 304. 
tempted to resist buyer's increased demands during a war, the buyer was upheld because of his past history as a large-scale operator. ${ }^{52}$ At the trial, the jury was told to consider the history and previous scope of buyer's business and its normal growth, but to disregard the war and other unlooked-for influences in determining the permissible increase; and that seller need not deliver all buyer might want because of a radical change in the market price or other causes not fairly within the contemplation of the parties. ${ }^{53}$

Where seller's complaint is that the demanded requirements are too small, rather than too large, similar tests are applied. Where buyer lays off part of his sales force or curtails production because of lack of demand, he is not liable to seller for any reduction in requirements. ${ }^{54}$ If, on the other hand, the cut in staff is dictated by a desire to avoid selling at a loss or a very small profit, buyer should be liable for the amount of requirements which would result from a full staff. 55 Sometimes a decrease in requirements results from buyer's employment of a substitute for the seller's item. ${ }^{\tilde{\sigma} 6}$ The present attitude of the courts seems to be that buyer agreed only to take what he needed of item $X$; if item $Y$ is more to buyer's liking he is not bound to forego its use in favor of $X . .^{57}$ For example, where a requirements buyer replaced worn-out equipment with a modern plant which enabled him to utilize waste heat, thereby reducing his requirements of natural gas, the court held him not in breach, stating that a requirements buyer does not breach by keeping abreast of modern developments. ${ }^{58}$ Where, however, a buyer resorted to the use of a substitute for seller's product until prices rose, at which time he demanded that seller resume supplying his requirements, the court excused seller from further performance on the ground that buyer's conduct had amounted to a breach since it was not motivated by good faith business reasons. ${ }^{59}$

52. Anaheim Sugar Co. v. Jenkins \& Co., 274 Fed. 504 (9th Cir. 1921). See also Jenkins \& Co. v. Anaheim Sugar Co., 247 Fed. 958 (9th Cir. 1918), cert. denied, 257 U.S. 658 (1922).

53. Anaheim Sugar Co. v. Jenkins \& Co., 274 Fed. 504, 507-8 (9th Cir. 1921) (reviewing and affirming the instructions of the trial court). Courts in allowing large increases have stated, however, that unconscionable conduct will not be allowed. See, e.g., New York Central Ironworks Co. v. United States Radiator Co., 174 N.Y. 331, 335, 66 N.E. 967, 968 (1903).

702 (1920).

54. Cf. Helena L. \& R. Co. v. Northern Pac. Ry. Co., 57 Mont. 93, 186 Pac.

55. Compare Dawson Cotton Oil Co. v. Kenan, McKay \& Speir, 21 Ga. App. 688, 94 S.E. 1037 (1917).

56. See Loudenback Fertilizer Co. v. Tennessee Phosphate Co., 121 Fed. 298 (6th Cir. 1903).

57. Southwest Natural Gas Co. v. Oklahoma Portland Cement Co., 102 F.2d 630 (10th Cir. 1939); McKeever, Cook \& Co. v. Canonsburg Iron Co., $138 \mathrm{~Pa}$. 184, 16 Atl. 97 (1888). But cf. General Crushed Stone Co. v. Trimpey, 28 North. 360 (Pa. C.P. 1942) (cannot avoid requirements contract by substituting similar and competing product).

58. Southwest Natural Gas Co. v. Oklahoma Portland Cement Co., supra note 57 .

59. Loudenback Fertilizer Co. v. Tennessee Phosphate Co., supra note 56. 
A contract for the requirements of a new business presents special problems in the ascertainment of proper requirements. Since courts are reluctant to uphold these contracts because of the absence of past requirements ${ }^{80}$ where a non-established business' contract is enforced there is likely to be a stated maximum or minimum ${ }^{61}$ or an estimate, ${ }^{62}$ possibly calculated from existing conditions in like businesses or from surveys normally made by a person embarking on a new business venture. A seller who contracts with an unestablished business consciously takes the risk of fluctuations in the requirements of the unknown business; therefore, it would seem that such a contract should be valid in any case, with the buyer's good faith limiting the requirements which can be demanded.

Under the Code:-The test whereby the extent of permissible variation will be measured under the Code is somewhat equivocal. According to the first clause of the requirements section all variations are subject to the test that they must occur in good faith. But the second clause appears to limit even a good faith variation to an amount not "unreasonably disproportionate to a stated estimate" or, in the absence of a stated estimate, to the "normal or otherwise comparable prior" requirements. Thus, except in the case of a new business which has no history of requirements, the Code may further limit variations.

A close analysis of the section, however, indicates that the exception clause is probably of limited application. The clause states that "no quantity unreasonably disproportionate" to any estimated or "normal or otherwise comparable prior output or requirements may be tendered or demanded." " 33 There is a problem in interpreting the meaning and effect to be given the words "tendered or demanded." Is "tendered" to refer only to output sellers and "demanded" only to requirements buyers, or do both words apply equally to both types of contracts? If the good faith requirements of buyer's business have increased to the point where they may be deemed "unreasonably disproportionate" to estimated or prior requirements, unless "tendered" applies to requirements contracts the seller is in a better position than the buyer. He may force the buyer to take all good faith requirements from him rather than merely a reasonably proportionate amount, while buyer may not enforce the contract beyond the reasonable variation; thus seller could benefit from a price decline while

60. See cases cited note 13 supra; Loewus \& Co. v. Vischia, 2 N.J. 54, 65 A.2d 604 (1949). See also, Comments, 48 Mich. L. Rev. 362 (1950); 26 IND. L.J. 111 (1950).

61. Texas Co. v. Pensacola Maritime Corp., 279 Fed. 19 (5th Cir. 1922).

62. Compare Ferenczi v. Natural Sulphur Co., 11 N.J. Misc. 262, 166 Atl. 477 (1933), with Edison Electric Illuminating Co. v. Thacher, 229 N.Y. 172, 128 N.E. 124 (1920).

63. It could be argued that "normal . . requirements" is not limited to normal prior requirements but can refer to requirements normal for the type of business. Since it seems unlikely that such an elusive standard was intended, the better interpretation is probably that both "normal" and "otherwise comparable" refer to prior requirements of buyer's business. 
buyer could not take advantage of a rising market. There seems to be no explanation for this distinction.

On the other hand, should the buyer's good faith requirements decline an unreasonably disproportionate amount, seller may force buyer to take up to the reasonable variation if "demanded" means ordered or requested. This would seem to be the interpretation intended by comment 3 which states that "an agreed estimate is to be regarded as a center around which the parties intend the variation to occur." But this analysis leads to a result, contrary to comment 2's claim that good faith discontinuance is permissible, that the Code prohibits discontinuance under any circumstances. Discontinuance, if anything, would constitute an unreasonably disproportionate variation. But the requirements section would work a radical, and probably unexpected, change in the law if it were interpreted to prohibit good faith discontinuance of requirements and a construction to avoid this result is desirable. In some cases the doctrine of impossibility of performance would mitigate this result, but it is doubtful if good faith discontinuance was intended to be limited to cases of impossibility alone. ${ }^{64}$ One interpretation to save the right of good faith discontinuance would be to construe the word "unreasonable" to permit a court to consider the cause of the variation rather than its magnitude; but the juxtaposition of the words "unreasonably disproportionate" militates against such a reading. Another and more reasonable construction of the exception clause is that "demanded" has the connotation of a buyer making demands upon his seller for delivery. Thus, the exception protects the seller only from demands unreasonably in excess of the stated estimate or prior requirements, but does not guarantee to the seller orders of at least a reasonably proportionate minimum. However, while buyer would not be in breach if he in good faith orders less than a reasonably proportionate minimum, the seller would be justified in refusing to deliver any goods not already delivered. The seller would not be in breach in so doing, because the buyer has no right to demand an amount "unreasonably disproportionate."

It may be argued that this section is meant to embody an intent of the parties at the time of making the contract that the requirements will not substantially deviate above or below a stated estimate or prior requirements; that is, the estimate or prior requirements represents the reasonable expectations of the parties and should not be tampered with. But to say this is to attribute to the agreement characteristics of the ordinary contract for a definite amount rather than those of a requirements contract. ${ }^{65}$ A requirements contract by its nature manifests a desire for flexibility in the quantity of goods sold in order to meet ordinary business fluctuations. To restrict the requirements closely to estimates or prior requirements would abrogate this chief purpose of such contracts; it is not likely that such a result was envisioned by the Code. ${ }^{66}$ Rather is it more feasible to

64. See UCC §2-615, comment 9.

65. Compare United States v. Republic Bag \& Paper Co., 250 Fed. 79 (2d Cir. 1918); Wadell v. Phillips, 133 Md. 497, 105 At1. 771 (1919).

66. See UCC \& $2-306$, comment 2. 
suppose that the proviso in question was designed to remedy a specific problem, i.e., the buyer's demanding a quantity of goods greatly disproportionate to that expected by the parties in order to take advantage of market conditions at the seller's expense. The same problem does not exist in the case of lower demands even when they are disproportionate to the estimate or prior requirements, because under any circumstances the buyer must take all of his requirements from seller and has little to gain by decreased requirements. ${ }^{\text {"7 }}$ Here both parties suffer from adverse market conditions.

The preceding analysis, when applied to the pre-Code law defining the quantity of requirements, indicates that the greatest change effected by the Code may come not from the good faith provision but from the limitation to a reasonably proportionate amount. The meaning of "good faith" under the Code is not perfectly clear, but it would seem that generally the results of decided cases will not be changed by this provision, since courts appear for the most part to have applied a good faith standard in the past. The Code does clarify, and in some cases changes, the result where buyer's good faith requirements become unreasonably higher than a stated estimate or prior requirements. Assume a contract for the requirements of a going business with past requirements of 100 tons of steel annually; for good faith reasons these requirements rise to 300 tons. Under some decided cases ${ }^{68}$ and under the good faith provision, seller would be required to furnish 300 tons, but the clause excepting unreasonably disproportionate amounts places a ceiling on demands allowable here. This result, dictated by the prior requirements (and estimate) proviso of the Code, is probably a reasonable one viewed from the standpoint of the parties' intention. Typically, the parties would not contemplate that the requirements would rise unreasonably above the past standards or a stated estimate.

Where present requirements decrease considerably, there is a serious problem as to whether the Code's previous requirements provision changes prior law. Assume, for instance, past requirements (or a stated estimate) of 300 tons and present good faith requirements of 50 tons. Under the law prior to the Code, the contract probably would be upheld for the 50 tons so long as the decrease was for a "good faith" reason. ${ }^{69}$ The same result would obtain under the Code in this case if the stated estimate or prior requirement proviso were interpreted to allow good faith decreases in order to save the right to cease operations. ${ }^{70}$

67. See Note, 28 CoL. L. Rev. 223 (1928).

68. Holmes \& Co. v. Detroit, 158 Mich. 137, 122 N.W. 506 (1909); Sherman Mach. \& Iron Works v. Carey, Lombard, Young \& Co., 100 Okla. 29, 227 Pac. 110 (1924); cf. Dailey Co. v. Clark Can Co., 128 Mich. 591, 87 N.W. 761 (1901); Anaheim Sugar Co. v. Jenkins \& Co., 274 Fed. 504 (9th Cir. 1921); Andrews Coal Co. v. Board of Directors, 151 La. 695, 92 So. 303 (1922). See also Ehrenworth v. Stuhmer \& Co., 229 N.Y. 210, 128 N.E. 108 (1920) (orders for bread increased gradually in seven years from 50 or 60 to three or four hundred loaves per week; contract held enforceable.).

69. Brawley v. United States, 96 U.S. 168 (1877) ; Kellogg Co. v. Standard Steel Fabricating Co., 189 F.2d 629 (10th Cir. 1951).

70. See text following note 64 supra. 
If, on the other hand, "no quantity unreasonably disproportionate" is construed to require a conclusion that the parties must not increase or decrease the quantity of goods sold in relation to prior requirements or a stated estimate, then it would seem that the law prior to the Code is changed.

\section{CONCLUSION}

The requirements section of the Code purports to apply ". . . the general approach . . . [of the Code] which requires the reading of commercial background and intent into the language of any agreement and demands good faith in the performance of that agreement." 71 Since the Code cannot explicitly answer all problems which may arise, resort to commercial background and the parties' intent should be helpful in resolving ambiguities. Although the Code's good faith standard has removed any doubt which remains as to the validity of most requirements contracts, there is a possible exception for a contract for the requirements of a non-established business, where a problem of uncertainty may remain. Consideration of commercial background and probable intent of the parties suggests that no requirements contract should be held invalid for uncertainty, since uncertainty is bargained for and its risk assumed in these contracts. Likewise, the intent to make a binding contract for a non-established business should not be over-ridden by the requirement of a duty to enter business. It is unclear whether such a duty exists under the Code; the most reasonable interpretation of the parties' intent would be to find an expectation that the business venture would be undertaken, but it is not unreasonable to say that the contract applies only if business is entered.

The amount of requirements which will be considered proper by the Code is subject to the general limitation of good faith, which results in little change in prevailing case law and will generally be consistent with the intent of the parties. Probably the additional limitation to an amount not unreasonably disproportionate to a stated estimate or prior requirements is only a ceiling on the amount which buyer can require seller to supply. If this is the only effect to be given the "unreasonably disproportionate" provision, the good faith standard, which applies in every case, will continue to be the most significant limit on the amount of the requirements. Placing a ceiling on the good faith requirements which seller can be forced to supply is probably in accord with the parties' intention in most cases, where unlimited liability of seller can be disastrous for him if a rising market causes an excessive increase in buyer's good faith requirements. The fact that in some cases the parties may have intended unlimited liability of the seller, which intent cannot be given effect under the Code, merely points up the fact that the goal of the Code must be to provide the

71. UCC $\$ 2-306$, comment 1. 
most reasonable rule for a majority of cases; some anomalous results must remain under any codification. These results, of course, can be prevented initially by careful drafting of requirements contracts, especially where conflicts appear between the Code's language and the comments thereto. The most important guarantee of the Code's success, however, lies in the careful application of its provisions in a manner consonant with business practices. 